\title{
Проблемы и перспективы оценки генетического разнообразия лиственниц
}

\author{
(C) Шарифьянова Ю.В ${ }^{1}$., Михайлова Е.В ${ }^{2 *}$. \\ ${ }^{1}$ Башкирский Государственный университет \\ Россия, Республика Башкортостан, 450076 г. Уфра, улица Заки Валиди, 32.
}

${ }^{2}$ Институт биохимии и генетики УФИЦ РАН

Россия, Республика Башкортостан, 450054 г. Уфра, улица Проспект Октября, 71.

*E-mail mikhele@list.ru

Среди растений рода Larix (Лиственницы) встречаются редкие образцы с декоративной формой кроны. Особенный интерес представляют генетические исследования таких образцов с целью развития методов их селекции и усиления мер охраны. На данный момент накоплен обширный материал по исследованию генетических ресурсов различных видов лиственниц. Разработаны группы молекулярно-генетических маркеров, позволяющих провести популяционно-генетический анализ, изучить структуру генома и генетическое разнообразие лиственниц. В связи с этим, перспективно применение полученных ранее знаний, для исследования генетического материала Кужановских лиственниц, являющихся достоянием Республики Башкортостан.

Ключевые слова: молекулярно-генетические методы, Кужановские лиственницы, генетическое разнообразие, ДНК-маркеры

Кужановские лиственницы, предположительно являющиеся формой лиственницы Сукачева (L. sukaczewii Dyl.) [1] - уникальный памятник природы Башкортостана. Их особенность заключается в раскидистой, шаровидной форме кроны, когда как обычно лиственницы имеют выраженный прямой ствол. Произошедший в 2020 году акт вандализма показал, как пагубное воздействие человека может в дальнейшем привести к сокращению и даже полному исчезновению столь редких и необыкновенных деревьев, 11 из которых уже находятся под угрозой гибели в Башкирии. Ввиду их малочисленности и уникальности нельзя недооценивать всю важность и необходимость принятия более строгих охранных мер.

Одним из решающих аргументов в пользу усиления защитных мероприятий может стать установление причины особенности фрормы кроны лиственниц. Однако, на данный момент существует несколько версий, объясняющих механизм возникновения необычного внешнего вида деревьев, среди которых однозначно достоверной нет. Основная гипотеза - инактивация апикального доминирования, приводящая к преимущественному росту боковых побегов, а не центрального. Причиной изменений, по мнению ученых, может быть мутация, приводящая к нарушению гормональной регуляции морфогенеза, или инфекция. Что бы установить какая из гипотез верна, стоит использовать генетические методы исследования.

Сложность исследования генетического материала семейства хвойных связана, вопервых, с большим содержанием фенольных соединений, что в значительной степени затрудняет выделение чистой ДНК. Во-вторых, с большим объемом ядерного генома, 
в 4-9 раз превышающий геном человека и состоящий на 70-80 \% из высокоповторяющихся элементов [2].

В последние годы появились новые возможности исследования генетической информации с использованием молекулярных методов анализа. Одними из инструментов изучения генетических процессов являются молекулярно-генетические маркеры. Большой вклад в исследование лиственниц сделан с помощью анализа маркеров ДНК митохондриальных и хлоропластных генов. Известна работа, в которой с использованием метода RAPD (Random Amplified Polymorphic DNA) выявлена связь японской лиственницы к лиственницам с Корейского полуострова [3].

Для исследования генетического полиморфизма популярно применение микросателлитных ДНК-маркеров (SSR-маркеры). Ранее для микросателлитных фррагментов были разработаны маркеры для лиственницы японской (L. kaempferi Sarg.) - группа bcLK [4], лиственниц альпийской (L. Iyallii Parl.) и западной (L. occidentalis Nutt.) группы - UAKLY $[5,6]$ и UBCLX [7]. Полиморфизм лиственницы сибирской (L. sibirica Ledeb.) был выявлен группой маркеров bcLK: bcLK056, bcLK224, bcLK232, bcLK235 и bcLK260 [8]. Из ISSR-праймеров (межмикросателлитные маркеры) для популяционно-генетического анализа ДНК лиственницы эфффективны следующие пять: (AC)8СТ, (ACC)6G, (AGC)6C, (GAC)6C, (CA)6GT [9].

На данный момент секвенирован полный геном лиственницы Сибирской (8463518 GenBank ID) и Тонкочешуйчатой (L. kaempferi, 23484598 GenBank ID). Это позволяет проводить биоинформатический поиск и подбор не только универсальных генетических маркеров, но и конкретных генов, которые могут быть задействованы в формировании особой формы кроны.

Таким образом, в настоящее время накоплен обширный материал о структуре, генетическом разнообразии, внутри- и межвидовой дифференциации популяций большого числа различных видов лиственниц. Использование мирового опыта позволит изучить генотип Кужановских лиственниц.

\section{Литература}

1. Суюндуков, И. В. О сохранении уникальных Кужановских лиственниц на территории памятника природы «Урочище Ултык-Карагас хр. Крыктытау» // Материалы Всероссийской научно-практической конференции смеждународным участием «Актуальные вопросы охраны биоразнообразия на заповедных территориях». 24 - 26 ноября 2020 г., Уфpa, C. 398

2. Kuzmin D. A., Feranchuk S. I., Sharov V. V., Cybin A. N., Makolov S. V., Putintseva Y. A., Oreshkova N. V., and Krutovsky K. V. Stepwise large genome assembly approach: A case of Siberian larch (Larix sibirica Ledeb) // BMC Bioinformatics. 2019. №20. P. 36 - 46

3. Kisanuki H., Ide Y., Isoda K., Shiraishi S. Molecular analysis of taxa in the genus Larix using randomly amplified polymorphic DNA. Improvement of larch (Larix sp.) for better growth, stem form and wood quality // Proc. of an Intern. Symp. Gap, 2002. P. $475-484$

4. Isoda K., Watanabe A. Isolation and characterization of microsatellite loci from Larix kaempferi \\Molecular Ecology. 2006. V.6, I.3. P. $664-666$. 
5. Khasa D.P., Newton C.H., Rahman M.H., Jaquish B., Dancik B.P. Isolation, characterization, and inheritance of microsatellite loci in alpine larch and western larch // Genome. 2000. №43 (3) P. 439 - 448.

6. Khasa D.P., Jaramillo-Correa J.P., Jaquish B., Bousquet J. Contrasting microsatellite variation between subalpine and western larch, two closely related species with different distribution patterns // Molecular Ecology. 2006. V.15, I.13. P. 3907 - 3918

7. Chen C., Liewlaksaneeyanawin C., Funda T., Kenawy A., Newton C.H., El-Kassaby Y.A. Development and characterization of microsatellite loci in western larch (Larix occidentalis Nutt.) // Molecular Ecology Resources .2009. V.9, I.3. P. $843-845$

8. Кулаков Е.Е.,. Сиволапов В. А.,. Воробьева Е. А., Сиволапов А. И. Генетическая изменчивость лиственницы Сукачева (Larix Sukaczewii Djil.) в географрических культурах под Воронежем // Лесотехнический журнал. 2018. №1. С. 35 - 40

9. Нечаева Ю.С., Боронникова С.В., Юсупов Р.Р., Хайнце Б. Изучение полиморфизма ISSR-маркеров в природных и искусственных популяциях лиственницы // Фундаментальные исследования. 2013. № 6-6. С. 1426 - 1431. 